\title{
HUBUNGAN OBESITAS UMUM DAN OBESITAS SENTRAL DENGAN PENYAKIT JANTUNG KORONER PADA PASIEN DI BLU/RSUP. PROF. DR. R. D. KANDOU MANADO
}

\author{
${ }^{1}$ Tracey C. C. W. Rompas \\ ${ }^{2}$ A. Lucia Panda \\ ${ }^{3}$ Starry H. Rampengan
}

\author{
Bagian Ilmu Penyakit Dalam Universitas Sam Ratulangi \\ traceycindy@ymail.com
}

\begin{abstract}
Abstrak: Penyakit jantung koroner (PJK) merupakan penyakit kardiovaskuler yang menyebabkan kematian nomor satu di dunia. Awalnya obesitas dianggap sebagai faktor yang memberikan kontribusi pada risiko penyakit PJK melalui faktor lain berhubungan seperti hipertensi, dislipidemia, namun telah dibuktikan juga bahwa distribusi jaringan lemak berpengaruh pada tingginya risiko penyakit jantung koroner. Obesitas ditentukan berdasarkan indeks massa tubuh (IMT) dan lingkar pinggang. Tujuan Penelitian ini adalah peneliti ingin mengetahui hubungan IMT dan lingkar pinggang penderita PJK di BLU/RSUP. Prof. Dr. R. D. Kandou Manado.

Penelitian ini bersifat pengamatan analitik dengan disain potong lintang. Populasi ialah pasien dengan penyakit jantung koroner di poliklinik Jantung BLU/RSUP Prof. Dr. R. D. Kandou Manado selama periode November 2012 yang memenuhi kriteria inklusi dan eksklusi sehingga diperoleh besar sampel 62 pasien. Sampel dipilih berdasarkan accidental sampling method.

Menurut analisis univariat pasien yang mengalami PJK sebanyak 82,3\% dari total sampel dan 86,7\% penderita PJK tergolong memiliki lingkar perut dan IMT diatas normal. Hasil pengujian bivariat dengan kaikuadrat dengan nilai kritis kemaknaan 0,05 didapatkan nilai $p=0,367$ untuk kategori IMT dengan PJK dan nilai $p=0,135$ untuk lingkar perut. Keduanya menunjukkan hubungan yang tidak signifikan.

Dari penelitian ini ialah menunjukkan tidak ada hubungan yang signifikan antara obesitas umum dan obesitas sentral dengan PJK pada pasien di poli jantung BLU/RSUP Prof. Dr. R. D Kandou Manado periode November 2012.
\end{abstract}

KataKunci : Obesitas, Lingkarperut, Penyakit Jantung Koroner

Abstract: Coronary heart disease (CHD) is cardiovascular disease that the first causes of death in the world. Obesity was initially considered as a factor that contributes to the risk of CHD by other factors related such as hypertension, dyslipidemia, but has also proved that the distribution of fat tissue effect on the high risk of coronary heart disease. Obesity is defined by body mass index (BMI) and waist circumference. Purpose of this study the researchers wanted to know the relationship of BMI and waist circumference of patients with CHD in BLU/RSUP. Prof. Dr. R. D. Kandou Manado.

The observation of this study is cross-sectional analytical design. The population was patients with CHD at the cardiac ward in the clinic of internal medicine BLU/RSUP Prof. Dr. R. D. Kandou Manado hospital during the period November 2012 that met the inclusion and exclusion criteria in order to obtain a sample size of 62 patients. Samples were selected based on accidental sampling method.

According to univariate analysis of patients with CHD as much as $82.3 \%$ of the total sample, and $86.7 \%$ of patients classified as having CHD abdominal circumference and BMI above normal. Bivariate test results with kai-squared significance the critical value 0.05 obtained for $p=0.367$ BMI categories with CHD and $p=$ 0.135 for waist circumference, both showed no significant relationship.

The conclusion of this study is to show there is no significant relationship between general obesity and central obesity and coronary heart disease in patients with CHD in the heart of poly BLU/RSUP Prof. Dr. R. D. Kandou Manado November 2012 period.

Keywords: Obesity, Abdominal Circumference, Coronary Heart Disease 


\section{PENDAHULUAN}

Perubahan pola hidup masyarakat saat ini menyebabkan pula perubahan pola penyakit, dari penyakit infeksi dan rawan gizi ke penyakit-penyakit degeneratif, diantaranya adalah penyakit jantung dan pembuluh darah (kardiovaskuler) dan akibat kematian yang ditimbukannya. Hingga kini penyakit jantung menjadi penyebab kematian nomor satu di dunia. ${ }^{(1)}$

Penyakit jantung koroner (PJK) adalah penyempitan atau penyumbatan arteri atau arteri-arteri yang memasok aliran darah ke otot jantung sehingga terjadi kekurangan suplai darah oksigen ke otot jantung. ${ }^{(2)}$

Pada saat ini penyakit jantung koroner telah menempati angka prevalensi 7,2\% pada tahun 2007 di Indonesia (data Rikesdas 2007). Walaupun angka prevalensi PJK tidak setinggi penyakit lain seperti penyakit infeksi, PJK masih dianggap sebagai penyumbang angka kematian di Indonesia. ${ }^{(3)}$ Overweight (berat badan lebih) adalah keadaan dimana Berat Badan (BB) seseorang melebihi BB normal. Menurut WHO (2000) untuk wilayah Asia Pasifik seseorang dikategorikan berat badan lebih jika mempunyai Indeks Masa Tubuh $\geq 23 \mathrm{~kg} / \mathrm{m} 2$. $^{(4)}$

World Health Organization (WHO) memperkirakan saat ini ada 1,6 miliar orang dewasa yang memiliki berat badan lebih (overweight) dan sekurang kurangnya ada 400 juta diantaranya mengalami faktor kegemukan (obesitas), jumlah itu diperkirakan akan meningkat pada tahun 2015 menjadi 2,3 miliar orang dewasa yang mengalami overweight dan 700 juta diantaranya mengalami obesitas. ${ }^{(5)}$

Individu dengan obesitas memiliki peningkatan resiko terjadinya penyakit kardiovaskular dan gangguan metabolik seperti penyakit jantung koroner, aterosklerosis, hipertensi, dislipidemia, diabetes dan gagal jantung. ${ }^{(6)}$ Obesitas diklasifikasikan oleh American heart association (AHA) sebagai faktor risiko modifikasi mayor untuk penyakit jantung koroner pada tahun $1988 .{ }^{(7)}$

Hasil penelitian membuktikan bahwa terdapat hubungan erat antara obesitas dan faktor risiko penyakit kardiovaskular seperti diabetes mellitus tipe II, dislipidemia, hipertensi dan penyakit jantung koroner. ${ }^{(8)}$

\section{METODE PENELITIAN}

Penelitian yang dilakukan bersifat analitik dengan pendekatan cross sectional, yaitu mengumpulkan data primer dari status pasien penyakit jantung koroner di Poliklinik Jantung BLU RSUP Prof. DR. R. D. Kandou Manado selama periode November 2012 dan menentukan hubungan antara obesitas umum dan obesitas sentral dengan penyakit jantung koroner. Populasi dalam penelitian ini adalah seluruh pasien penyakit jantung koroner yang berobat di poliklinik jantung Prof. DR. R. D. Kandou Manado selama periode November 2012. Besar Sampel dalam penelitian ini menggunakan accidental sampling method dimana sampel yang diambil adalah sampel yang datang ke poli jantung pada periode penelitian yaitu bulan November 2012 dengan memperhatikan kriteria sampel. Kriteria inklusi yaitu penderita yang telah didiagnosis penyakit jantung koroner di poli jantung BLU RSUP. Prof. Dr. R. D Kandou, penderita penyakit jantung koroner yang bersedia dijadikan sebagai subjek penelitian, penderita yang Non- Penyakit Jantung Koroner yang bersedia di ukur IMT dan Lingkar perut. Variabel dalam penelitin ini ialah Umur, jenis kelamin, status obesitas umum,status obesitas sentral. Instrumen yang digunakan untuk penelitian ini ialah alat tulis menulis, weight scale, height scale/ microtoise, tali ukur (centimeter). Penelitian ini diawali dengan mengumpulkan pasien yang sudah terdiagnosis dengan penyakit jantung koroner, menentukan pasien obesitas dengan menggunakan IMT dan ukur lingkar pinggang, setelah itu data diolah berdasarkan variabel penelitian dan disajikan dengan cara menyusunnya dalam bentuk tabel, grafik dan presentasi.

\section{HASIL PENELITIAN}

Penelitian ini dilakukan di poli jantung BLU/RSUP Prof. DR. R. D. Kandou Manado terhadap 62 sampel, yang berlangsung selama periode November 2012-januari 2013, didapatkan karakteristik in dividu sebagai berikut: 
Tabel 1.Karakteristik individu

\begin{tabular}{llllll}
\hline Variabel & $\mathrm{N}$ & Minimum & Maksimum & Rerata & Standar Deviasi \\
\hline Umur & 62 & 37 & 81 & 59,82 & 11,471 \\
IMT & 62 & 19 & 39 & 26,42 & 4,741 \\
Lingkar perut & 62 & 76 & 130 & 98,06 & 13,332
\end{tabular}

Ket : IMT = Indeks Massa Tubuh

Tabel 2.Frekuensi Jenis Kelamin

\begin{tabular}{lll}
\hline Jenis Kelamin & Frekuensi & $\%$ \\
\hline Laki-laki & 38 & 61,3 \\
Perempuan & 24 & 38,7 \\
Total & 62 & 100,0 \\
\hline
\end{tabular}

Tabel 3.Frequensi IMT

\begin{tabular}{lll}
\hline IMT & Frekuensi & $\%$ \\
\hline Normal & 17 & 27,4 \\
Pre-Obese & 7 & 11,3 \\
Obese Tipe I & 23 & 37,1 \\
Obese Tipe II & 11 & 17,7 \\
Obese Tipe III & 4 & 6,5 \\
\hline Total & 62 & 100 \\
\hline
\end{tabular}

Tabel 4.Frekuensi Kategori Lingkar Perut

\begin{tabular}{lll}
\hline Kategori Lingkar Perut & Frekuensi & $\%$ \\
\hline Bukan Obese Sentral & 17 & 27.4 \\
Obese Sentral & 45 & 72.6 \\
Total & 62 & 100.0 \\
\hline
\end{tabular}

Tabel 5.Frekuensi Kejadian PJK

\begin{tabular}{lll}
\hline & Frekuensi & $\%$ \\
\hline Non-PJK & 11 & 17.7 \\
PJK & 51 & 82.3 \\
Total & 62 & 100 \\
\hline
\end{tabular}

\section{PEMBAHASAN}

Pada tahun 2012, dalam kurun waktu 2 bulan yaitu dari tanggal 1 November 2012 sampai dengan tanggal 31 desember 2012, ditemukan penderita penyakit jantung koroner sebanyak 51 pasien yang bersedia untuk di periksa. Ditemukan pula 12 pasien yang non penyakit jantung koroner yang ditemukan dan bersedia untuk dilakukan pemeriksaan Indeks Massa Tubuh dan Lingkar perut guna untuk melengkapi data yang akan diolah.

Pada penelitian ini ditemukan perbandingan antara jumlah pasien laki-laki dan jumlah pasien perempuan, dengan presentase jumlah pasien laki-laki lebih banyak dibandingkan jumlah pasien perempuan.Namun tidak signifikan, yaitu dari 62 kasus di BLU RSUP Prof.DR. R. D.Kandou Manado ditemukan 38 pasien $(61,3 \%)$ berjenis kelamin laki-laki dan 24 pasien $(38,7 \%)$ berjenis kelamin perempuan, 6 orang laki-laki bukan PJK (15,8\%), dan 32 orang menderita PJK $(84,2 \%)$. Dari sampel perempuan didapatkan terdapat 5 orang bukan PJK $(20,8 \%)$, dan 19 orang menderita $\operatorname{PJK}(79,2 \%)$. 
Menurut penelitian yang dilakukan Anies dkk, penyakit jantung koroner lebih sering dialami oleh laki-laki dibandingkan perempuan.Hal ini disebabkan karena pada umumnya laki-laki lebih sering melakukan aktifitas fisik dibandingkan perempuan.Hal ini juga dipengaruhi oleh faktor gaya hidup, seperti merokok dan alkohol. ${ }^{(9)}$

Dari 62 kasus yang diteliti, ditemukan IMT Normal yang bukan PJK ada 5 orang (29,4\%), dan yang menderita PJK 12 orang $(70,6 \%)$. Pasien dengan kategori IMT Pre-Obesitas yang bukan PJK ada 2 orang ( 26,8\%), dan yang menderita PJK 5 orang $(71,4 \%)$. Pasien dengan kategori IMT Obesitas tipe I yang bukan PJK ada 2 orang ( 8,7\%), dan yang menderita PJK 21 orang (91,3\%). Pasien dengan kategori IMT Obesitas tipe II yang bukan PJK ada 2 orang $(18,2 \%)$, dan yang menderita PJK 9 orang $(81,8 \%)$.

Hal ini berbanding terbalik dengan penelitian dari Irfan Arief bahwa IMT yang tinggi mempunyai prediksi bermakna pada semua kasus penyakit jantung koroner dan menemukan risiko relatif penyakit kardiovaskuler berkaitan dengan meningkatkan berat badan adalah lebih tinggi diantara umur 30 - 44 tahun. ${ }^{(10)}$

Berdasarkan hasil penelitian didapatkan bahwa nilai $\mathrm{p}=0,135$ yang artinya nilai $>0,05$ adalah tidak mempunyai hubungan yang signifikan antara obesitas sentral dan penyakit jantung koroner. Ada pendapat yang mengatakan bahwa kejadian aterosklerosis koroner tidak disebabkan secara langsung oleh obesitas yang hanya merupakan faktor tambahan bukan faktor utama. Penelitian yang dilakukan Periode Januari- Desember 2010 menunjukkan hubungan yang tidak bermakna atau tidak signifikan antara obesitas dengan kejadian PJK. ${ }^{(12)}$ Hasil penelitian ini memang tidak sejalan dengan teori yang dikeluarkan oleh American Heart Association (AHA) yang menyatakan bahwa obesitas diklasifikasikan sebagai faktor risiko modifikasi mayor untuk penyakit jantung koroner pada tahun 1988. ${ }^{(13)}$ Penelitian ini juga bertolak belakang dengan penelitian sebelumnya yang dilakukan Muhammad Denial, yang menyatakan terdapat hubungan signifikan antara obesitas sentral dan kejadian PJK.Pengukuran obesitas dengan mennggunakan lingkar pinggang sehingga didapatkan obesitas sentral jauh lebih baik dibandingkan dengan pengukuran obesitas berdasarkan IMT. Beberapa penelitian sebelumnya telah menunjukan bahwa lemak abdominal/visceral merupakan lemak jahat yang banyak dihubungkan dengan kejadian penyakit jantung koroner. Laporan dari National Cholesterol Education Program (NCEP) pada expert panel on detection, evaluation and treatment of high cholesterol in adult (adult treatment Panel III/ATPIII) menyatakan lingkar pinggang sebagai bagian dari sindrom metabolik yang mendapat perhatian lebih serius. Pada penelitian sebelumnya dari populasi dewasa di pedesaan dan perkotaan di Bali didapatkan bahwa lingkar pinggang merupakan prediktor sindrom metabolik yang sangat baik dimana lingkar pinggang berhubungan kuat dengan komponen sindrom metabolik lainnya. Lingkar pinggang jauh lebih baik digunakan sebagai prediktor sindrom metabolik dibandingkan dengan IMT. Pada penelitian ini dengan populasi PJK usia lanjut didapatkan lingkar pinggang tidak berhubungan dengan komponen sindrom metabolic lainnya, tetapi berhubungan kuat dengan kadar adiponektin plasma. Obesitas sentral mempunyai ratio prevalensi 5 kali lebih tinggi untuk mendapatkan hipoadiponektinemia dibandingkan dengan non obesitas sentral. Tidak demikian halnya dengan IMT. ${ }^{(14-15)}$

Tidak adanya hubungan yang bermakna dalam penelitian ini kemungkinan dikarenakan banyaknya faktor risiko lain penyebab PJK yang tidak dapat diubah seperti faktor keturunan atau genetik, faktor usia dan jenis kelamin, juga faktor lain yang berhubungan dengan perilaku seperti kebiasaan merokok, mengkonsumsi alkohol dan riwayat penyakit lainnya seperti diabetes melitus, hipertensi, pola makan abnormal atau penyakit infeksi yang penah menyerang darah dan pembuluh darah. ${ }^{(13)}$ Selain itu periode penelitian yang pendek mengakibatkan jumlah sampel yang ditemukan juga sedikit, kemungkinan lainnya yang menyebabkan penelitian ini tidak didapatkan hubungan signifikan yaitu karena pada sampel yang tidak menderita PJK juga terdapat obesitas sentral, sebaliknya juga didapatkan jumlah yang besar penderita PJK yang memiliki IMT dan lingkar pinggang yang normal yang mungkin disebabkan karena berat badan sudah terkontrol karena dalam penelitian ini tidak diambil data mengenai lama berobat juga riwayat obesitas sebelumnya. Faktor lain yang mungkin menjadi penyebab berbedanya hasil penelitian dengan penelitian sebelumnya yaitu jenis penelitian, dimana penelitian lain menggunakan jenis penelitian kasus kontrol bahkan penelitian kohort yang membutuhkan waktu serta jumlah sampel yang besar. 


\section{SIMPULAN}

Jenis kelamin laki-laki lebih berpotensi untuk terkena penyakit jantung koroner, hasil penelitian menunjukkan bahwa tidak ada hubungan yang bermakna antara obesitas umum dan obesitas sentral dengan penyakit jantung koroner, hubungan obesitas umum dan obesitas sentral tidak mempunyai hubungan signifikan yang kuat dimana $\mathrm{p}=0,135$ dan $\alpha>0,05$.

\section{SARAN}

Diperlukan penelitian dengan jumlah sampel yang lebih besar untuk mendapatkan hasil bahwa tidak ada hubungan antara obesitas umum dan obesitas sentral terhadap kejadian penyakit jantung koroner di BLU RSUP Prof. DR. R. D. Kandou Manado. Diperlukan hasil pemeriksaan laboratorium dan riwayat genetik dari pasien agar dapat menghasilkan hasil yang lebih maksimal dalam penelitian. Pasien diharapkan dapat mengenali gejala awal dari penyakit jantung koroner dan melakukan pemeriksaan rutin sehingga dapat mendeteksi dini penyakit.jantung koroner. Perlu dilakukan perbaikan dan penyempurnaan dalam sitem pengisian dan penyimpanan data penyakit atau status pasien dalam bentuk rekam medik di BLU RSUP Prof. DR. R. D. Kandou Manado

\section{UCAPAN TERIMA KASIH}

Terima kasih ditujukan kepada:

1) dr. A. Lucia Panda, SpPD, SpJP (K), FIHA sebagai Dosen Penguji I.

2) dr. Frans Wantania, SpPD sebagai Dosen Penguji II.

3) Semua pihak yang secara langsung maupun tidak langsung yang telah memberikan ide/gagasan dalam penulisan skripsi ini. 


\section{DAFTAR PUSTAKA}

1. Kandou GD. Makanan etnik minahasa dan kejadian penyakit jantung koroner. Jurnal Kesehatan Masyarakat Nasional. 2009;4:42-8.

2. Shapiro PA, Wulsin LR. Cardiovascular disorder. Sadock BJ, Sadock Va, Ruiz P, editor. Kaplan and Sadocks's Comprehensive textbook of psychiatry. Edisi 9. New York: Lippincott Williams and Wilkins; 2009. hal.2251-61

3. Firdaus I. Pharmaccoinvasive Strategy in Acute STEMI. Jurnal kardiologi Indonesia, vol 32,no.4.2012

4. Depkes RI. Obesitas dan Kurang Aktifitas Fisik Menyumbang 30\% Kanker. Pusat Komunikasi Publik. Sekertariat Jendral Departemen Kesehatan Republik Indonesia 2009. Di Unduh dari: http://www.depkes.go.id/index.php/berita/press-release/137. last update februari 2009

5. Apa itu obesitas. Februari 2010.Diakses dari : http://www.news-medical.net/health/What-isObesity-(Indonesian).aspx

6. Wilson PW, D'Agostino RB, Sullivan L, Parise H, Kannel WB. Overweight and obesity as determinants of cardiovascular risk: the Framingham experience. Arch Intern Med. 2002; 162: 1867-72

7. Krauss RM, Winston M. Obesity Impact on Cardiovascular Disease. American Heart Association, Inc: 2012. diakses dari: http://circ.ahajournals.org/content/98/14/1472.full

8. WHO. Obesity: Preventing and Managing the Global Epidemic. Report of a WHO consultation. Geneva, Switzerland: WHO, 2000. Diakses dari: http://www.who.int/mediacentre/factsheets/fs311/en/

9. Anies,2006. Waspada Ancaman Penyakit Tidak menular, PT. Elex Media Komputindo, Jakarta

10. Kairupan J, Lefrand R. Hubungan Antara Indeks Massa Tubh dengan Profil Lipid pada Infark Miokard Akut.Jurnal Kardiologi Vol. XXVI, No.2 April-Juni 2002

11. Monika , Zainal M. Purwani Eka L., Hubungan Antara tipe obesitas dengan tipe penyakit jantung coroner di poli jantung rumah sakit umum darah cengkareng periode januari desember 2010.Skripsi. Universitas Pembangunan Nasional Veteran Jakarta 2010

12. Hubert H B, Feinleib M, McNamara PM, Castelli WP. Obesity as an independent risk factor for cardiovascular disease: a 26-year follow-up of participants in the Framingham heart study. Circulation 1983;67:968-977

13. Gotera W, Aryana IGPS, Saraswati MR, Budiartha AAG, Sutanegara IND, Suastika K, et al. Studi epidemiologi obesitas dan dislipidemia di kota Denpasar. Majalah Penyakit Dalam Udayana2002;3:94-8

14. National cholesterol education program (NCEP) Expert panel on Detection, evaluation and treatment oh high blood cholesterol in adult ( adult treatment panel III). Third report of the National cholesterol education program (NCEP) Expert panel on Detection, evaluation and treatment oh high blood cholesterol in adult (adult treatment panel III) final report. Circulation 2002;106:3143-421 